\title{
RAISING KNOWLEDGE OF ILLOCUTIONARY ACTS AND IMPLICATURES USED IN A THESIS EXAMINATION CONTEXT FOR STUDENTS OF ENGLISH LANGUAGE EDUCATION STUDY PROGRAM
}

\author{
Margana \\ State University of Yogyakarta
}

\begin{abstract}
This paper deals with raising knowledge of the illocutionary acts and implied meanings for students of English education study program. It aims to describe the types of illocutionary acts, illocutionary forces, and conversational implicatures used in the thesis examination. Such types of knowledge should be well understood as the knowledge confers a clear description of the use of speech acts in the thesis examination.

More specifically, students of English education study programs should be aware of the types of illocutionary acts, namely representatives, directives, commissive, expressive, and declarative which are further classified according to the illocutionary forces of each illocutionary act. Added to this, the knowledge of conversational implicatures: generalised conversational implicatures and particularised conversational implicature are also of great importance to minimise mis-conception and mis-interpretation of speech acts which possible occur in the thesis examination practices.
\end{abstract}

Key words: illocutionary acts illocutionary forces implicatures

\section{INTRODUCTION}

A language, for example, English is defined as a system of sounds, symbols, or signs that convey meanings. It is commonly used by human beings to express their ideas, feelings, emotions, and the like in different settings of communications which include natural and formal settings. In natural settings, 
English is widely employed by some Indonesian society members such as becak drivers, tour guides, cashiers and the like to communicate with non-domestic tourists in some tourism spots like Malioboro, Borobudur, Bali, and others. In formal settings, English is employed by many Indonesian educationalists, namely English or non-English teachers, English or non-English lecturers, English trainers and the like as a means of classroom communications beside Indonesian. In international seminars or conferences, English is also employed by the presenters as a means of presentations or by participants as a means of asking questions to the presenters. Added to this, English is also used as a means of a communication between the board of the examiners and the examinees when they are involved in the thesis examination, for example, thesis examination at English language education study program.

The use of English in the thesis examination by the board of the examiners is unique in nature. The uniqueness is that the thesis examination is dominated by question and answer practices between the examiners and the examinees. The questions to some extent do not really ask the examinees the content of the thesis drafts but the questions as reflected in the form of the speech acts are primarily aimed at reconfirming the examinees' understanding of what they have written in their thesis drafts. Therefore, the utterances of the board of the examiners can be comprehensively analysed when students of English language education study program have sufficient knowledge of pragmatics, which include the knowledge of illocutionary acts, illocutionary forces, and conversational implicatures.

In reference to the above issue, this article presents the nature of illocutionary acts, the types of illocutionary forces of each illocutionary act and the conversational implicatures. The exploration of the three issues is of great importance for students of English language study program who are engaged in the thesis examination. By understanding the three issues, mis-interpretation and communication barriers could be minimised.

\section{LITERATURE REVIEW}

\section{Illocutionary Acts and Illocutionary Forces}

In relation to pragmatics, Yule (1996:47) states that the pragmatics is primarily concerned with the issue of a speech act which means an action performed via utterances which have specific labels such as apology, complaint, 
compliment, invitation, promise or request, and the like. According to her, the speech act may embody locutionary, illocutionary, and perlocutionary acts. The locutionary act refers to an utterance that is tied in terms of sense and reference. The illocutionary act is defined as the making of a statement, for example, offering, promising, etc in expressing an utterance, by virtue of the conventional force associated with it. The per-locutionary act means the bringing about of effects on the audience by means of the utterance.

In lieu with the illocutionary act, Searle in Finch (2000:182) classifies the illocutionary acts into five types, namely (1) representative, (2) directive, (3) commissive, (4) expressive, and (5) declarative. The term representative is defined as one of the illocutionary acts which commits the speaker to the truth of the uttered proposition. It is commonly used to represent a state of affairs (Finegan et al., 1997:L344). Such a type of the illocutionary act is divided into some illocutionary forces which include stating, suggesting, boasting, complaining, claiming, and announcing (Leech, 1983:105). Further, Cutting (2008:14) adds some illocutionary forces of the representative, namely describing, hypothesizing, insisting, and predicting.

The second type of the illocutionary act is directive which is defined as asking the hearer to do something. With the use of directive, the addresser attempts to get the addressee to do some actions as he/she wants. This illocutionary act is subdivided into some types which include (1) commanding, (2) requesting, (3) suggesting, (4) inviting, (5) questioning, and (6) warning. The term commissive refers to committing the addresser to some future course of actions. In other words, it deals with an action which will be or will not be done in the future course. This illocutionary act is categorised into some illocutionary forces which include (1) promising, (2) vowing, (3) offering, (4) threatening, and (5) refusing.

The fourth illocutionary act is expressive. It is defined as a speech act, which expresses a psychological state. This can be in the form of stating pleasure, pain, likes, dislikes, anger, joy, sorrow, and the like. The illocutionary act of expressive has some illocutionary forces such as (1) greeting, (2) thanking, (3) apologizing, (4) complimenting, (4) stating pleasure, (5) stating pain, (6) stating doubt, (7) stating confusion, (8) stating surprise, (9) stating panic, (10) stating anger, and (11) stating dislike. Another type of the illocutionary act is declarative. It refers to a speech act of which effects immediately change an institutional state of affairs. Added to this, it tends to rely on elaborated extra-linguistic institutions. 
This illocutionary act comprises some illocutionary forces which include (1) excommunicating, (2) declaring war, (3) christening, (4) marrying, (5) firing from employment, and others Finch (2000:182). This type of the illocutionary act is rarely used in communication practices including in the thesis defence because it is limited to ceremonial events.

Of the five types of illocutionary acts, four types of illocutionary acts are commonly used in communication practices including the communication performed by board of examiners in the thesis defence. They include (1) representative, (2) directive, (3) commissive, and (4) expressive. The following provides examples of the four illocutionary acts and forces used in the thesis defence.

\section{Illocutionary Acts and Illocutionary Forces Used in the Thesis Examination}

In the thesis defence, there are four types of illocutionary acts which are commonly used by the board of examiners. Each illocutionary act is discussed below.

\section{Representative}

The following presents some examples of illocutionary forces of representative as commonly performed by the board of examiners. Each illocutionary force has a linguistic feature as presented in the bold forms.

Table 1. The examples of illocutionary forces of representative

\begin{tabular}{|c|c|c|}
\hline No & Types of & Examples \\
\hline 1 & Stating an opinion & $\begin{array}{l}\text { E-1 : In my opinion, at least there are two factors } \\
\text { to successfully comprehend the English } \\
\text { text. They are schematic knowledge and } \\
\text { systemic knowledge. }\end{array}$ \\
\hline 2 & Informing & $\begin{array}{l}\text { C : Dear examinee, let me inform you that in } \\
\text { the first part of the examination, you are } \\
\text { given time fifteen minutes to present the } \\
\text { summary of your thesis and then in the } \\
\text { second part, the examiners will ask you the } \\
\text { details of your research. }\end{array}$ \\
\hline
\end{tabular}




\begin{tabular}{|c|c|c|c|}
\hline 3 & Agreeing & E-1 & $\begin{array}{l}\text { : Giving the students more chance. Now, } \\
\text { what do you mean about applying some } \\
\text { new speaking activities? What do you mean } \\
\text { by speaking activities? } \\
\text { : Some new speaking activities include } \\
\text { conversation games, role play, and so on } \\
\text { that I have explained to you, Sir. } \\
\text { : Yes, I agree with you. }\end{array}$ \\
\hline 4 & Arguing & E-1 & $\begin{array}{l}\text { : How come? I dont think that students } \\
\text { motivation is one of the external factor. } \\
\text { Not, like this one. }\end{array}$ \\
\hline 5 & Explaining & E-2 & $\begin{array}{l}\text { : Because the class bilingual, did you find } \\
\text { that one? I think you mean is because the } \\
\text { classes is bilingual right? When you use } \\
\text { because it must be clause, when you use } \\
\text { because of must be phrase. }\end{array}$ \\
\hline 6 & Convincing & E-1 & $\begin{array}{l}\text { : What text did you give to the students? } \\
\text { Narrative, Nyai Loro Kidul ? Roro, Loro. } \\
\text { Loro moto. Roro itu kan julukan (The } \\
\text { word loro refers to an address system). It is } \\
\text { easier to pronounce Loro but it should be } \\
\text { Roro not Loro. Ya Roro ya, not Loro (The } \\
\text { correct one is Roro not Loro). }\end{array}$ \\
\hline 7 & Predicting & E-1 & $\begin{array}{l}\text { : I believe that if the students are familiar } \\
\text { with the schematic knowledge they will be } \\
\text { easier to make sense of the English texts } \\
\text { What do you think about it? }\end{array}$ \\
\hline 8 & Convincing & E-1 & $\begin{array}{l}\text { : I believe that if the students are familiar } \\
\text { with the schematic knowledge they will be } \\
\text { easier to make sense of the English texts } \\
\text { What do you think about it? }\end{array}$ \\
\hline 9 & Announcing & $\mathrm{C}$ & $\begin{array}{l}\text { : After we have a long discussion dealing } \\
\text { with your performance, we come to the } \\
\text { agreement that you pass this exam, but you } \\
\text { have to make some revisions. }\end{array}$ \\
\hline
\end{tabular}




\section{Directives}

In the thesis defence, the illocutionary act in the form of directive is often found. The following exemplifies the illocutionary forces of the illocutionary act of directive. Each illocutionary force has a linguistic feature as presented in the bold forms.

Table 2. The examples of the illocutionary forces of directive

\begin{tabular}{|c|c|c|}
\hline No & Types of & Examples \\
\hline 1 & Commanding & $\begin{aligned} \text { E-1 : Now open to page } 54 \text {. You can display } \\
\\
\text { Table } 14 \text {. Please tell me the meaning of } \\
\text { the information of each column. }\end{aligned}$ \\
\hline 2 & Requesting & $\begin{array}{l}\text { C : Would you please show us the } \\
\text { identification of the problem in your } \\
\text { slide? } Y a \text {, this one. }\end{array}$ \\
\hline 3 & Suggesting & $\begin{array}{ll}\text { E-1 : I think its better for you to give an } \\
\text { emphasis that students still found } \\
\text { difficulties in comprehending text for the } \\
\text { first cycle. }\end{array}$ \\
\hline 4 & Inviting & $\begin{aligned} \mathrm{C} \quad \text { : Now, I invite you to present your thesis } \\
\text { draft in } 15 \text { minutes. The floor is yours. }\end{aligned}$ \\
\hline 5 & Questioning & $\begin{array}{l}\text { E-1 : How did the teacher learn English based on } \\
\text { your interview? Did they have or attend } \\
\text { special English training from school or } \\
\text { from the government? }\end{array}$ \\
\hline 6 & Warning & $\begin{aligned} \text { C : Please highlight that vocabulary should be } \\
\text { embedded in the macro-language skills. It is } \\
\text { not explicitly taught for the students of } \\
\text { secondary school levels. Dont teach } \\
\text { vocabulary separated from the macro } \\
\text { language skills. Do you understand this } \\
\text { point? }\end{aligned}$ \\
\hline
\end{tabular}




\section{Commissive}

In the thesis defence, the illocutionary act in the form of commisive is often found. The following exemplifies the illocutionary forces of the illocutionary act of commisive. Each illocutionary force has a linguistic feature as presented in the bold forms.

Table 3. The examples of illocutionary forces of commisive

\begin{tabular}{|l|l|l|}
\hline No & $\begin{array}{l}\text { Types of } \\
\text { Illocutionary Forces }\end{array}$ & Examples \\
\hline 1 & Promising & C $\begin{array}{l}\text { : In the first part of examination you have } \\
\text { done } 15 \text { minutes to present the summary of } \\
\text { your research and then we will ask you } \\
\text { questions and will give you necessary } \\
\text { advice for the revision of your report. }\end{array}$ \\
\hline 2 & Offering & E-1 $\begin{array}{l}\text { : Do you want to drink first before } \\
\text { continue my next questions ? It seems to } \\
\text { me that you are nervous. Just relax. Dont } \\
\text { be afraid of me. }\end{array}$ \\
\hline 3 & Threatening & E-1 $\begin{array}{l}\text { : You have to carefully revise all mistakes } \\
\text { that I found on your thesis. Otherwise, I do } \\
\text { not want to ratify your thesis. }\end{array}$ \\
\hline
\end{tabular}

\section{Expressive}

In the thesis defence, the illocutionary act in the form of expressive is often found. The following exemplifies the illocutionary forces of the illocutionary act of expressive. Each illocutionary force has a linguistic feature as presented in the bold forms. 
Table 4. The example of the illocutionary forces of expressive

\begin{tabular}{|c|c|c|c|}
\hline No & Types of & Exal & ples \\
\hline 1 & Greeting & $\mathrm{C}$ & $\begin{array}{l}\text { Good morning, everyone. We are very } \\
\text { pleased to invite you to put for the thesis } \\
\text { examination. }\end{array}$ \\
\hline 2 & Thanking & $\mathrm{C}$ & $\begin{array}{l}\text { Thank you so much for your presentation } \\
\text { and Id also like to congratulate you on } \\
\text { accomplishing your thesis draft, this is } \\
\text { writing draft. }\end{array}$ \\
\hline 3 & Apologizing & E-1 & $\begin{array}{l}\text { I I am so sorry, I could not stay here until } \\
\text { the end because I have to join the meeting } \\
\text { at Rectorate. Sorry for making you } \\
\text { inconvenience. }\end{array}$ \\
\hline 4 & Complimenting & $\begin{array}{l}\text { E-1 } \\
\text { C }\end{array}$ & $\begin{array}{l}\text { I am pleased to be your first examiner. First } \\
\text { of all, I would like to say congratulation } \\
\text { for your success in finalizing your thesis } \\
\text { draft. } \\
\text { : You did well enough in your } \\
\text { performance even though there are } \\
\text { weaknesses in there. }\end{array}$ \\
\hline 5 & Stating pleasure & $\mathrm{C}$ & $\begin{array}{l}\text { Board of the examiners, examinee Eko } \\
\text { Fabrianto and audience, its pleasure for } \\
\text { us this morning to have you to take the } \\
\text { examination of his thesis entitled } \\
\text { Improving Students Speaking Ability } \\
\text { through Contextualised Speaking Tasks. }\end{array}$ \\
\hline 6 & Stating a doubt & & $\begin{array}{l}\text { For me, internal factor is related to the } \\
\text { reader. It can be the motivation or the } \\
\text { ability of the reader. It is an internal factor. } \\
\text { The other factor is the teacher. It can be } \\
\text { the external factor. Perhaps, there are } \\
\text { other theories. }\end{array}$ \\
\hline 7 & Stating confusion & & $\begin{array}{l}\text { I dont quite understand why some are } \\
\text { included in the internal factors and some } \\
\text { others are included in the external } \\
\text { factors. }\end{array}$ \\
\hline
\end{tabular}




\begin{tabular}{|c|c|c|}
\hline 8 & Stating surprise & $\begin{array}{l}\text { E-2 : You have so many prints -out of data but } \\
\text { you didnt explain what they mean. How } \\
\text { come? Why happened to you? Ini } \\
\text { semuanya harus dilaporkan untuk item } 1 \\
\text { (This should be reported). }\end{array}$ \\
\hline 9 & Stating panic & $\begin{array}{l}\text { : Ehm.. ehm.. I have a meeting at Senate. } \\
\text { Let me give the opportunity to the first } \\
\text { examiners. Ehm.. I will be right back. }\end{array}$ \\
\hline 10 & Stating anger & $\begin{array}{l}\text { C : Do you get the first examiner's question? Do } \\
\text { you get the point of his question? She does not } \\
\text { understand it. It is terrible. } \\
\text { E-1 : How many percent is this, spelling? And } \\
\text { then total correct answer? 140. 94,9. So the } \\
\text { percentage? Is this about spelling or } \\
\text { pronunciation? How do you spell } 67.7 \% \text { ? } \\
\text { How do you write? Kok bisa, kok kamu bisan } \\
\text { ('How come')? We are testing what you } \\
\text { have done not your purpose? Kita bukan } \\
\text { ahli kebathinan ('We are not paranormal'). } \\
\text { Jadi yang diujikan adalah yang tertulis ('So } \\
\text { what I see is what you write'), "not what I } \\
\text { mean". }\end{array}$ \\
\hline 11 & Stating dislike & $\begin{array}{l}\text { : Could you explain that to me what you } \\
\text { mean with their writing ability is low? I } \\
\text { dont like the score when you are talking } \\
\text { writing ability. I dont believe in score . } \\
\text { But in writing ability, did you observe the } \\
\text { student skill ability? What typical mistake } \\
\text { did you find? }\end{array}$ \\
\hline
\end{tabular}

Note:

E-1 : The First Examiner C: Chair Person

E-2: The Second Examiner $\mathrm{S}:$ Student 


\section{Conversational Implicature}

In any communication practices, the speakers have intentional meanings which are not explicitly stated in their utterances. This drives the hearers to struggle hard to get the message which is implicitly stated in order to minimise communication barriers due to the unsaid information. The implied message in a conversation is called an implicature. Brown and Yule (1983: 31) state that an implicature is what the speaker can imply, suggest, or mean as distinct from what the speakers literally express. As it is not explicitly stated by speakers in their utterances, the hearers then need to make implication or suggestion in order to gain what the speakers mean through their utterances. Further, Horn and Ward (2006: 3) state that implicature is a component of speakers' meaning that constitutes an aspect of what is meant in the speakers' utterance without being part of what is said. Grundy (2008: 92) claims that an implicature is a meaning that is conveyed but not explicitly stated. To know the intended meaning of the speakers' utterances, the hearers must do a deep interpretation since the speakers' utterances usually have more than a literal meaning.

In terms of the types of implicatures, some experts classify the implicatures into two types, namely (1) conversational implicatures and (2) conventional implicatures. The conversational implicatures refer to a particular meaning as implicitly conveyed by the speaker in conversational practices (Cutting, 2008:35). In this case, the hearers are demanded to make an inference of the speakers' utterances. This type of implicatures is divided into two, namely (1) generalised conversational implicatures and (2) particularised conversational implicatures. The former may arise without any particular context or special scenario to deal with additional conveyed meaning (Yule, 1996:41). For example, the construction I saw a university student last Monday standing next to a pretty car exemplifies the generalised conversational implicature which informs that the student and the pretty car do not belong to the speaker. The latter deals with an implicature that requires very specific contexts in which inferences are needed. Such inferences are required to search out the conveyed meanings. The following presents the example of particularised conversational implicature.

John : May I have a ride tomorrow? My car is broken.

Yessica: My mother asks me to take her in the airport at dawn.

The above conversation shows that Yessica could not give a ride to John because she takes her mother in the airport. Such an inference requires particular contexts to interpret the implied meaning. 
Different to the conversational implicature, the conventional implicature deals with specific words and results in additional conveyed meanings when the words are employed (Yule, 1996:45). Mey $(1993 ; 104)$ urges that the conventional implicature cannot be changed by invoking another context as it is standardised by convention. Levinson (1983: 127) claims that the conventional implicature is treated as non-truth-conditional inferences, which are not generated from superordinate pragmatic principles like the maxims, but it is simply connected by conversation to particular lexical item. This suggests that such a type of the implicatures can be automatically interpreted by words as literally expressed without occurring in conversations and not depending on special contexts for its interpretation. For example, the word and in My mother ask me to buy apples and oranges means additional as the word and is a conjunction that links some similar items. In this case, it does not need a particular context to interpret the meaning of the word and.

\section{Conversational Implicatures in Thesis Examination}

As mentioned earlier, there are two types of conversational implicatures. They include generalised conversational implicatures and particularised conversational implicatures. Each is discussed below.

\section{Generalised conversational implicature}

$\mathrm{C}$ : Please highlight that vocabulary should be embedded in the macrolanguage skills. It is not explicitly taught for the students of secondary school levels. Don't teach vocabulary separated from the macrolanguage skills. Do you understand this point?

The above example shows that the speaker confers an implied meaning as shown in the bold forms. He wants to say that teaching vocabulary cannot be separated from the four macro-language skills, namely listening, speaking, reading and writing. Such an implied meaning is categorised as the generalised conversational implicature as the hearers do not need to apply specific knowledge to make sense of such utterances. See the other example below.

E-1: When you deal with a top-down processing in teaching reading, we give an emphasis of the use of sub-reading skills. It is better for you to add the sub-reading skills when you explain the use of top-down process in your literature review. 
The above example shows that the speaker has an implied meaning through the uttered expressions. He suggests that the examinee as the hearer includes the explanation of predicting, previewing, guessing, scanning, and the like to deal with the application of the top-down processing. The implied meaning is also classified as the generalised conversation implicature as it does not require a specific context to make sense of the used utterances.

\section{Particularised conversational implicature}

E-2 : Okay. We've got so many comments from Pak Harto. I think you should revise your thesis report as suggested by him.

$\mathrm{S}$ : Yes, sir. Thank you.

The above example performs that the second examiner urges that the examinee should highlight what the first examiner asks and commends on her thesis draft to gain the betterment of the thesis report. Added to this, the other implied meaning through his utterance is that he has only a few comments on the thesis report as the first examiner has already covered all part of the thesis draft.

$\mathrm{C}$ : I think we don't have any more question to ask. Could you please wait outside for the result of your performance.

The above example shows that the speaker signals that the thesis examination is up as a great number of questions have been asked and successfully answered by the examinee. Added to this, the speaker also asks the examinee to give privacy to the board of the examiners to discuss the result of the thesis examination. Such implied meanings require particular knowledge to make sense of the utterances. That is why such the implied meaning is categorised as the particularised conversational implicature.

\section{CONCLUSIONAND SUGESTION}

With regard to the above explanation, the knowledge of illocutionary acts and implied meanings is of great importance to students of English language education study program. The understanding of those issues facilitates them to easily make sense of the message in some communication practices in different contexts including in the context of a thesis defence which employs English as a means of communication. This relies on the fact that the use of English in the thesis defence is unique in nature. Therefore, students of English language education 
study program should be familiar with four types of illocutionary acts which include representative, expressive, commissive, and directive and the types of illocutionary forces of each illocutionary act mentioned which are commonly employed in the thesis defence.

Added to this, they have to be familiar with types of implicatures, namely generalised and particularised conversational implicatures. Such understanding is of great use to make sense of the implied meanings in order that mis-interpretation leading to the failure of their thesis examinations could be minimised. To sum up, raising knowledge of illocutionary acts and implied meanings used in the thesis examination to students of English language education study program is fruitful to establish open-minded graduates in lieu with use of English language in some different communication practices in order that mis-conception and misinterpretation of speech acts can be minimised.

\section{REFERENCES}

Brown, G. and G. Yule. (1983). Discourse Analysis. Cambridge: Cambridge University Press.

Cutting, J. (2008). Pragmatics and Discourse: a Resource Bookfor Students. New York:

Finch, G. (2000). Linguistic Terms and Concepts. London: Mac-Millan Press Ltd.

Finnegan, E., Blair, D. \& Collin, P. (1997). Language: Its Structure and Use. 2nd Ed. Australia: Harcourt Brace\& Co.

Grundy, P. (2008). Doing Pragmatics. London: Hodder Education.

Horn, L.R. and G. Ward. (2006). The Handbook of Pragmatics. Oxford: Blackwell Publisher.

Leech, G. (1983). Principles of Pragmatics. New York: Addison Wesley Longman Publishing

Levinson, S. (1983). Pragmatics. Cambridge: Cambridge University Press.

Mey, J.L. (1993). Pragmatics: An Introduction. Massachusetts: Best-set Typesetter Ltd.

Yule, G. (1996). Pragmatics. Oxford: Oxford University Press. 